\title{
The Effect of Good Corporate Governance and Political Connection on Value Firm
}

\author{
Agus Bandiyono \\ Politeknik Keuangan Negara STAN \\ Email: agusbandiyono@pknstan.ac.id; agus.bandiyono@gmail.com
}

\begin{abstract}
This study aims to determine the effect of applying good corporate governance and political connections to firm value. The data of this study are secondary data of manufacturing companies listed on the Indonesia Stock Exchange in 2014-2016. Data were analyzed using panel data estimation. The results of this study indicate that partial corporate governance has a positive and significant effect on firm value, political connection variables have a positive and significant effect on firm value and together corporate governance and political connections have a positive and significant effect on firm value.
\end{abstract}

Keywords: Political Connections, Good Corporate Governance, Firm Value, Financial Accounting.

\section{INTRODUCTION}

Firm value is one of the indicators used by investors to assess a company (Asriyani and Bandiyono, 2019). The higher the firm value of a company, the higher the investor's trust in the company and assume the company will be able to provide welfare to stakeholders. (Bandiyono and Murwaningsari, 2019). The company's management will try to maximize firm value to provide added value for shareholders. (Bandiyono and Augustine, 2019). Management seeks to implement corporate governance to increase firm value. (Wiagustini, 2014) states that the higher the value of the company, the greater the prosperity that will be received by the company owner.

Companies that have already gone public will certainly pay attention to corporate governance. One measure of management's success in increasing company value is one of which implements corporate governance which will have an impact on improving the company's image. (Bandiyono and Indrianto, 2019). A well-managed, professional company will have a positive impact on investors. Investors will assume that good corporate governance will provide substantial benefits and make investors feel safe to invest in the company. (Bandiyono and Aryani, 2019).

Implementation of Good Corporate Governance in companies today is expected to increase Firm Value. Firm value will increase if many investors are interested in investing their capital into the company. According to (Hermastuti, 2014), high company value is the desire of the owners of the company, because with high value shows the prosperity of shareholders is also high. Companies that apply the principles of good corporate governance are more attractive to investors than companies that do not apply the principles of Corporate Governance (Bandiyono and Pratama, 2019). 
Corporate governance in Indonesia has emerged since Indonesia was affected by the 1998 monetary crisis. In the 1998, many companies were affected by the monetary crisis, as evidenced by the number of companies that went out of business. According to (Velnampy, 2013), Corporate governance is a system consisting of a set of structures, procedures, and mechanisms designed for company management based on accounting principles that can increase company value in the long run.

Research conducted by (Septianto et al., 2017) states that Good Corporate Governance does not affect firm value, in this study Corporate Governance variables using independent audit committee indicators do not affect Firm Value. It is assumed that investors may not necessarily understand the capacity of the audit committee members on companies because this audit committee is only used as a structural formation of formalities in public companies to meet the requirements of Corporate Governance. (Irawan and Devie's, 2017) shows that corporate governance has a positive and significant effect on firm value in LQ 45 companies during the period 2012 to 2015 . This study shows that with increasing corporate governance, it will significantly increase firm value.

Firm value can also be formed because there is a reality between company management and the authorities. Management of companies that are directly or indirectly related will have an impact on the value of the company. In Indonesia, the case of political connections to firm value can be seen in PT. Saratoga Investama, Tbk when Sandiaga Uno was elected deputy Governor of DKI Jakarta the value of the company's shares rose very significantly. Likewise, when Sandiaga Uno failed to become the Vice President of the Republic of Indonesia, the share price of PT. Saratoga Investama, Tbk experienced a very significant decline. This indicates the strong political influence on firm value. This fact is supported by the opinion of (Coulomb and Sagnier, 2014): "Political majorities affect economic activity.

In developing countries, political connections play an important role in increasing firm value. Indonesia as a developing country with such a complex problem is very visible political connections. Companies that have a close relationship with the authorities will easily obtain projects from the government, permits and even tax avoidance. In the era of President Soeharto, entrepreneurs who had close relations with the authorities were rapidly developing and obtained various facilities, whereas entrepreneurs who lacked closeness with the authorities experienced difficulties in various aspects.

Political connections can also hurt the company. Much research has been done which shows that companies that have directors and commissioners who come from people close to the authorities have the potential for corruption. Assesses the involvement of political activities in business there is no positive benefit for the success of the company, it can even have a negative impact, based on several studies. He said companies with directors or commissioners who have political ties have the potential for acts of corruption and nepotism that have been widely reported by the media.

The company's political relationship with the authorities can be done in several ways such as appointing a board of commissioners from the leaders of the ruling political party, retired officials, or having ownership of the authorities in the company. At the beginning of President Joko Widodo's administration, it was very clear that there was a political connection, namely the appointment of party leaders and volunteers supporting the president to be a commissioner in SOEs without regard to their competence and expertise. 
(Wulandari, 2013) states that the board of directors and the board of commissioners of a politically connected company has a significant negative effect on company performance. (Kristianto, 2019) states that the proportion of independent directors who have political relations harms financial performance but does not affect market performance and, the proportion of managerial ownership that has political relations hurts market performance but does not affect financial performance. Third, company size and type of company have a significant influence on company performance (both financial performance and market performance).

\section{THEORETICAL REVIEW}

Agency Theory. In agency theory, it explains about two conflicting economic agents, principals and agents. An agency relationship is a contract in which one or more people (principals) govern another person (agent) to perform a service on behalf of the principal and authorize the agent to make the best decision for the principal (Ichsan, 2013). If the principal and agent have the same goals, the agent will support and carry out everything instructed by the principal.

Contradictions occur when the agent does not carry out the principal's orders for his own interests. In this study, the government is the principal while the company is the agent. The government that acts as the principal instructs companies to pay taxes in accordance with tax legislation. What happens is that the company as an agent prioritizes its interests in optimizing corporate profits so as to minimize expenses, including tax burden by tax avoidance. The manager of the company in power in the company for decision making as an agent has an interest in maximizing his profits with policies issued. The character of the company manager certainly influences the manager's decision to decide on his policy to minimize the burden including tax burden by considering various things such as sales growth or leverage.

Increased sales growth certainly illustrates increasing profits so that managers will think of maximizing profits in any way. Likewise with leverage, the leverage policy used by managers to obtain external funding for operational continuity will increase interest but reduce tax burden because of greater tax protection. These two things are considered by managers in deciding policies to maximize profits. This is what makes agency conflict.

Agency conflicts that occur between agents and principals can be minimized in various ways, one of which is by disclosure of corporate governance (Evianisa, 2014). According to the Forum for Corporate Governance in Indonesia (FCGI) in (Evianisa, 2014) regarding the definition of corporate governance is a set of regulations governing the relationship between shareholders, management (managers) of the company, creditors, government, employees as well as those holding internal and other external interests who relating to their rights and obligations.

Stakeholder Theory. The definition of stakeholders according to Freeman and McVea (2001) is any group or individual that can influence or be influenced by the achievement of organizational goals. Stakeholder theory is a theory that describes which parties thecompany is responsible for (Hemastuti,C.P, 2014). The company must maintain relationships with its stakeholders by accommodating the desires and needs of its stakeholders, especially stakeholders who have the power to the availability of resources used for operational 
activities of the company, for example labor, markets for company products and others (Chariri and Ghozali, 2007).

The emergence of stakeholder theory as a dominant paradigm further strengthens the concept that companies are responsible not only to shareholders but also to stakeholders (Maulida and Adam, 2012). In developing stakeholder theory, Freeman (1983) in Susanto Y.K. (2013) introduce the concept of stakeholders in two models, namely: (1) the policy and business planning model; and (2) the corporate social responsibility model of stakeholder management. In the first model, the focus is on developing and evaluating agreements 11 The company's strategic decisions with groups whose support is needed for the company's business continuity. It can be said that, in this model, stakeholder theory focuses on ways that companies can use to manage the company's relationships with its stakeholders. While in the second model, company planning and analysis is expanded to include external influences that may be opposite for the company. These opposing groups include regulatory bodies (government) with special interests who have a concern for social problems. Sustainability report is a report that is used to inform about economic, social and environmental performance. With this disclosure, the company is expected to be able to meet the information needs needed by stakeholders.

Good Corporate Governance. According to Cadbury (Lukviarman, 2016) states that Corporate Governance is concerned with holding the balance between economic and social goals and between individual and communal goals. The governance framework is there to encourage the efficient use of resources and equally to require accountability for the stewardship of those resources. The aim is to align as nearly as possible the interests of individuals, corporations, and society.

Good Corporate Governance according to the Organization for Economic Cooperation and Development (OCED) (Fadilah, 2011) corporate governance is the system by which business corporations are directed and controlled. The corporate governance structure specifies the distribution of rights and responsibilities among different participants in the corporation, such as the board, the managers, shareholders, and other stakeholders and spells out the rules and procedures and for making decisions on corporate affairs. By doing this, it also provides the structure through which the company objectives are set, and the means of attaining those objectives and monitoring performance.

According to article 3 of the Regulation of the Minister of State Enterprises Number PER01 / MBU / 2011 concerning the Implementation of Good Corporate Governance / GCG In BUMN, which consists of; 1) Transparency, 2) Accountability, 3) Responsibility, 4) Independence and 5) Fairness. According to the OECD in (Sedarmayanti (2012) GCG principles consist of 1) Fairness, 2) Disclosure and Transparency, 3) Accountability and 4) Responsibility.

Political Connections. (Faccio, 2006) defines political connections by A company is defined as connected with a politician if at least one of its large shareholders (anyone controlling at least 10 percent of voting shares) or one of its top directors (CEO, president, vice president, or secretary) is a member of parliament or a minister, or is closely related to a top politician or party. Close relationships can be through friendship, former heads of state or prime ministers, past directorships held, foreign politicians, or longstanding relationships with political parties. 
(Bianchi and Viana, 2014) state that political connections are formed through direct relationships, namely the relationship between top managers, employees, shareholders, and politicians with current or past political activities, and political connections formed from indirect relationships, namely contributions to campaigning activities and activities in practice try to persuade legislators for specific interests. (Purwoto, 2011) argues that "... politically connected companies are companies that in certain ways have political ties or seek closeness with politicians or the government." Political connections make it easy for companies to get loans with credit lines that can be extended. This happens because the lender also receives direct economic support from the government where the company is connected and there is a guarantee from the government that the politically connected borrower and the lender will be given bailout funds when both are experiencing a financial crisis (Faccio, 2006).

The benefits of political connections according to (Kim and Zhang, 2016) include the low pressure from the capital market to conduct transparency and potentially reduce political costs related to tax planning activities through tax aggressiveness. Not only that, that political connections also benefit companies to get access to the central government. Political connections will be increasingly apparent in countries with high levels of corruption. Although in reality corruption hurts the economy and the growth rate of a country, the same does not apply to political connections that are considered beneficial by many companies (Faccio, 2006).

Firm Value. (Ernawati and Widyawati, 2015) state that one of the things considered by investors in investing is the value of the company in which the investor will invest in. Based on the financial view the value of the company is the present value of future income (future free cash flow). The higher the value of the company, the greater the prosperity the company will receive. For companies that issue shares in the capital market, the price of shares traded on the stock exchange is an indicator of the value of the company

(Suffah and Riduwan, 2016) define the value of the company is the investor's perception of the company, which is often associated with stock prices. be considered the value of an investor in investing is the value of the company where the investor will invest. According to (Suad and Enny, 2012), the understanding of company value is the price a prospective buyer is willing to pay when the company is sold, the higher the value of the company, the greater the prosperity the company owner will receive.

According to (Brigham and Joel, 2014) Company value is defined as market value because the value of the company can provide maximum prosperity for shareholders if the company's stock price increases. Various policies are taken by management to increase the value of the company through increasing the prosperity of owners and shareholders as reflected in the share price. Measurement of company value according to (Brigham and Joel, 2014) uses the ratio of Price Earning Ratio (PER), Price to Book Value, and Tobins, Q.

Company Value according to (Noerirawan and Muid 2012), is a condition that has been achieved by a company as an illustration of public trust in the company after going through a process of activities for several years, namely since the company was founded until now. 


\section{THEORETICAL REVIEW}

The Effect of Good Corporate Governance Implementation on Firm Value. Research (Purbopangestu and Subowo, 2014) states that the implementation of good corporate governance does not affect firm value. Research (Tambunan et al., 2017) states that (1) institutional ownership, independent commissioners, and audit committees influence jointly or simultaneously the value of the company (Tobin's Q); (2) based on the results of the $t$ test conducted, among the variables of institutional ownership, independent commissioners, and audit committees that have the most dominant influence on firm value (Tobin's Q) are institutional ownership variables. Research by (Muryati and Suardikha, 2014) states that only independent audit committee variables hurt firm value while the other four independent variables have a positive effect on firm value.

Based on research that has been done shows that the application of good corporate governance has a positive effect on firm value.

Influence of Political Connections on Firm Value. Research conducted by (Dewanti, 2019) states that political connections but not significant positive effect on the value of the Company. Research conducted by (Tangke, 2019) states that political connection does not affect firm value. Research (Wang et al., 2018) states that political connections affect the value of companies where companies that have political connections with dismissed officials experience a decline in the value of equity. (Sharma et al., 2019) find significant positive effects of political connections on Chinese firms' decisions to enter export markets and on their subsequent export performance. We also find significant differences in these effects based on the type of firm ownership. (Ang et al., 2013) stated that Politically connected firms have higher managerial ownership and tend to be smaller than non-PC firms, rendering them more susceptible to poorer governance practices.

Some of these studies show that political connections affect firm value.

Relationships influence the implementation of good corporate governance and connected Politics on Firm Value can be described as the following Figure:

Figure 1. the implementation of good corporate governance and connected Politics on Firm Value

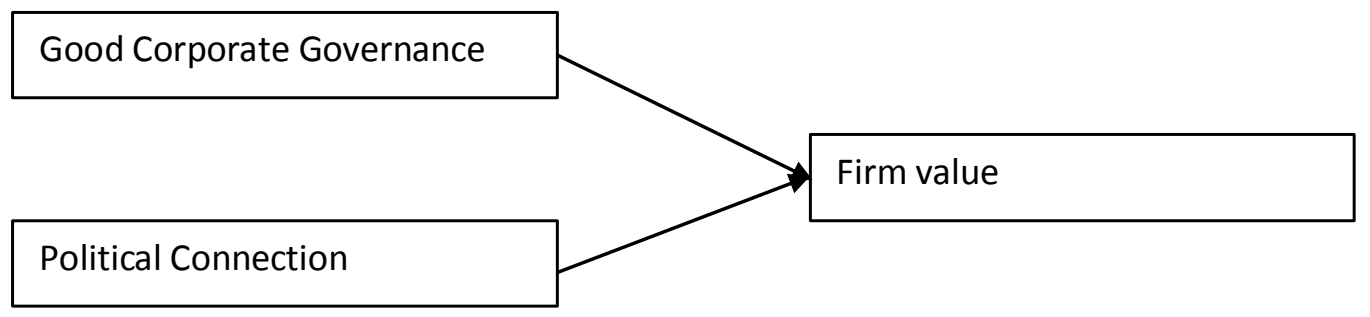




\section{HYPOTHESIS AND MODEL ANALYSIS}

Hypothesis. Based on the framework above hypothesis in this study are as follows:

H1 Good Corporate Governance positive and significant impact on the Firm Value

H2 Political Connections have a positive and significant effect on Firm Value

$\mathbf{H}_{3} \quad$ Good Corporate and Political Connections together have a positive and significant effect on firm value.

Analysis Model. Based on the hypothesis above, this study used multiple linear regression analysis on panel data to explain the relationship between variable $\mathrm{X}$ and $\mathrm{Y}$. The model is as follows:

Note:

$$
\mathrm{Y}=\mathrm{a}+\mathrm{b}_{1} \mathrm{X}_{1}+\mathrm{b}_{2} \mathrm{X}_{2}+\mathrm{e}
$$

$\mathrm{Y} \quad=$ Firm Value

$\mathrm{X}_{1} \quad=$ Good Corporate Governance

$\mathrm{X}_{2} \quad=$ Political Connection

$\alpha \quad=$ intercept regression constant

$\mathrm{e} \quad=$ error term

\section{METHODOLOGY}

This research uses descriptive quantitative research methods with the Secondary Data Analysis (ADS) approach. ADS is a method using secondary data as the main data source. Utilizing secondary data in question, namely by using a statistical test technique that is appropriate to obtain the desired information from the body of material or data that has been obtained in certain institutions or institutions (such as BPS, departments or educational institutions) to be processed systematically and objectively.

The quantitative research method expressed by Sugiyono is defined as: The research method as a method based on positivist philosophy; the method used to examine a particular population or sample; technique of sampling is usually carried out with the calculation of certain suitable sample techniques; data collection using research instruments and data analysis of quantitative / statistical nature with the aim to test the hypotheses that have been set especially for comparative and associative hypotheses.

Data analysis results in quantitative are usually presented using tables, frequency distribution tables, line or bar graphs, piecharts (diaram circles), and pictograms. For discussion of the results of the study will include in-depth explanation and interpretation of the data that has been presented to then produce conclusions that contain brief answers to the formulation of the problem based on the data that has been collected.

This research data uses secondary data from manufacturing companies listed on the Indonesia Stock Exchange. The sample selection uses a purposive sampling technique, by eliminating members of the population who do not have the following criteria. The company 
has an independent commissioner, the company publishes complete financial statements and the company makes a profit. Based on these criteria, a sample of 42 property sector companies listed on the Indonesia Stock Exchange (IDX) was obtained from 2014 to 2016.

This study uses panel data estimates. The panel data regression method consists of three methods, namely PLS (Pooled Least Square), FEM (Fixed Effect Model), and REM (Random Effect Model). Of the three approaches will be chosen which approach is most suitable. To choose the panel data regression model, two tests were conducted, namely the $\mathrm{F}$ test and the Hausman test. The F test is used to choose between the PLS (Pooled Least Square) model and the FEM (Fixed Effect Model) model and the Hausman test is used to choose between the FEM (Fixed Effect Model) or REM (Random Effect Model) models.

In the regression model estimation method using panel data can be done through three approaches, including:

Common Effect Model or Pooled Least Square (PLS). It is the simplest panel data model approach because it only combines time series data and cross sections. In this model, time and individual dimensions are not considered, so it is assumed that corporate data behavior is the same over various time periods. This method can use the Ordinary Least Square (OLS) approach or the least squares technique to estimate the panel data model.

Fixed Effect Model (FE). This model assumes that differences between individuals can be accommodated from their intercept differences. To estimate the Fixed Effects model panel data using variable dummy techniques to capture intercept differences between companies, intercept differences can occur due to differences in work culture, managerial, and incentives. However, the slopes are the same between companies. This estimation model is often called the Least Squares Dummy Variable (LSDV) technique.

Random Effect Model (RE). This model will estimate panel data where interruption variables may be interconnected between time and between individuals. In the Random Effect model, intercept differences are accommodated by the error terms of each company. The advantage of using the Random Effect model is to eliminate heteroscedasticity. This model is also called the Error Component Model (ECM) or the Generalized Least Square (GLS) technique.

\section{THE RESULTS OF STATISTICAL TESTS AND DISCUSSION}

Estimation Model Selection. Based on estimation techniques, panel data regression models can be estimated using three estimation methods, namely Pooled Least Square, Fixed Effect Model, and Random Effect Model. To determine the appropriate or suitable estimation engineering model, three-panel data regression tests were carried out namely; (1) F Restricted test to choose the Pooled Least Square or Fixed Effect Model, (2) If the test rejects the Fixed Effect Model then the Breusch - Pagan Lagrange Multiplier (LM Test) is then performed to choose the Pooled Least Square or Random Effect Model, (3), the Hausman test is done if the first or second test rejects the Pooled Least Square model. The Hausman test is performed to select the FEM or REM model.

F Restricted test estimation results are used to determine the appropriate estimation method between Pooled Least Square and Fixed Effect Model by looking at the lowest F probability value in the Fixed Effect Model output. 
Table 1. Regression Results Estimates of Common Effect

\begin{tabular}{|c|c|c|}
\hline Variable & Coefficient Std. Error t-Statistic & Prob. \\
\hline $\mathrm{C}$ & $0.213634 \quad 0.517765 \quad 3.464652$ & 0.0025 \\
\hline $\mathrm{CG}$ & $\begin{array}{lll}0.456987 & 0.519354 & 2.799818\end{array}$ & 0.0012 \\
\hline $\mathrm{KP}$ & 0.5448371 .8526580 .0326 & 0.212701 \\
\hline R-squared & Mean dependent var 0.916532 & 1.325157 \\
\hline Adjusted R-squared & 0.957357SD dependent var & 1.121459 \\
\hline $\mathrm{SE}$ of regression & 1.023152Akaike information criterion & 4.264521 \\
\hline Sum squared resid & 164.9832 Schwarz criterion & 5.332119 \\
\hline Log-likelihood & 112.2548 criteria Hannan-Quinn. & 3.292872 \\
\hline F-statistic & 1.833450 Durbin-Watson stat & 0.754445 \\
\hline Prob (F-statistic) & 0.001281 & \\
\hline
\end{tabular}

Source: (Eviews output results 10, 2019)

Table 2. Regression Results Fix Effect

\begin{tabular}{ccccc}
\hline Variable & Coefficient & Std. Error & t-Statistic & Prob. \\
\hline C & 0.885524 & 0.076121 & 5.060700 & 0.0000 \\
CG & 1.344585 & 0.111394 & 1.243182 & approxim \\
& & & & ately \\
& & & & 0.0042 \\
KP & 0.235651 & & & 0.652578 \\
& 0.982356 & & & \\
& 0.0317 & & & \\
\hline
\end{tabular}

Effects Specification

Cross-section fixed (dummy variables)

Period fixed (dummy variables)

\begin{tabular}{lll} 
R-squared & 0.874912 Mean dependent var & 0.318436 \\
Adjusted R-squared & 0.935367 SD dependent var & 0.122648 \\
SE of regression & 0.421414 Akaike info criterion & 1.162492 \\
Sum squared resid & 0.255121 Schwarz criterion & 1.621535 \\
Log-likelihood & 77.02158 Hannan-Quinn criteria. & 0.963251 \\
F-statistic & 4.256536 Durbin-Watson stat & 1.735442 \\
Prob (F-statistic) & 0.352632 & \\
\hline
\end{tabular}

Source: (Eviews output results 10, 2019) 
Table 3. F Restricted

\begin{tabular}{lllcc}
\hline \multicolumn{1}{r}{ Variable } & \multicolumn{1}{c}{ Coefficient } & Std. Error & t-Statistic & Prob. \\
\hline KP & 0.124452 & 0.578988 & 0.136362 & 0.2727 \\
CG & 0.364765 & & & 0.187685 \\
\multicolumn{1}{c}{ C } & 1.2315970 .0270 & & \\
& 0.654234 & 0.453274 & 2.110328 & 0.0025 \\
\hline R-squared & 0.235227 Mean dependent var & & 0.218286 \\
Adjusted R-squared & 0.485002 SD dependent var & 0.254645 \\
SE of regression & 0.177354 Akaike information criterion & 1.317396 \\
Sum squared resid & 0.712332 Schwarz criterion & 1.985406 \\
Log-likelihood & 31.57888 Hannan-Quinn criteria. & 1.382941 \\
F-statistic & 3.632718 Durbin-Watson stat & & 1.753187 \\
Prob (F-statistic) & 0.087552 & & \\
\hline
\end{tabular}

Source: (Eviews output results 10, 2019)

F Restricted test estimation results are used to determine the best estimation method between Pooled Least Square and Fixed Effect Model by looking at the probability value (F statistic). Based on the table above it is known that the calculated $F$ value is 3.632718 and the $\mathrm{F}$ table is 3.0681 ( $\mathrm{F}$ arithmetic > F table) so that the more appropriate model to use is the fixed-effect model. The fixed effect model is a model used to estimate that there are differences between companies that can still be tolerated from differences in their intercepts.

The Lagrange Multiplier test is then performed to choose between the Pooled Least Square method and the Random Effect Model with the Hypothesis $\mathrm{H}_{0}=$ the method used is Pooled Least Square and $\mathrm{H}_{1}=$ the method used is the Random Effect Model. Criteria for decision-making is $\mathrm{BP}>\alpha=0,05)$, then $\mathrm{H}_{0}$ is accepted and $\mathrm{BP}<\alpha=0.05$ then $\mathrm{H}_{\mathrm{H}}$ is rejected

Table 4. Test Results Lagrange Multiplier

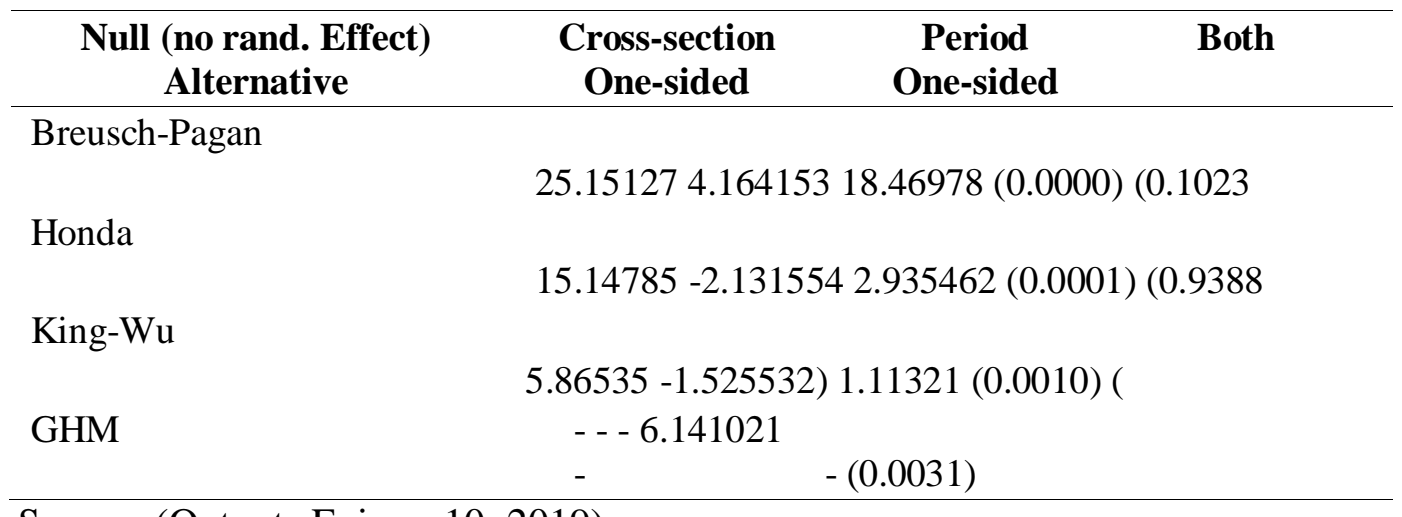

Source: (Outputs Eviews 10, 2019)

Based on table 4 above, it can be seen that the value of prob. Breush-Pagan (BP) is in the column both, which is 0.0435 and smaller than the degree of freedom of 5\% $(0.0456$ $<0.05)$. From these results, it can be concluded that the random-effects model is more appropriate to use than the Pooled Least Square. 
The F Restricted Test and the Lagrange Multiplier Test reject the Pooled Least Square model then the Hausman test is then performed. The Hausman test is used to determine the appropriate estimate between the Fixed Effect Model and the Random Effect Model.

Table 5. Results of Random Effect Regression

\begin{tabular}{|c|c|c|c|c|}
\hline Variable & Coefficient & Std. Error & t-Statistic & Prob. \\
\hline $\mathrm{C}$ & 1.213645 & 0.513368 & 2.364086 & 0.0196 \\
\hline \multirow[t]{2}{*}{$\mathrm{CG}$} & 0.879331 & & & 0.776919 \\
\hline & 1.9933160 .0291 & & & \\
\hline \multirow[t]{4}{*}{ KP } & 0.304889 & & & 0.286740 \\
\hline & 1.9804760 .0488 & & & \\
\hline & Effects Specific & & & \\
\hline & & & SD & Rho \\
\hline Cross-section random & & & 0.000000 & 0.0000 \\
\hline \multirow[t]{2}{*}{ Idiosyncratic random } & & & 2.0450 & 0.521549 \\
\hline & Weighted Statis & & & \\
\hline R-squared & 0.735419 Mean & ependent var & & 0.718452 \\
\hline Adjusted R-squared & $0.857566 \mathrm{SD} \mathrm{de}$ & endent var & & 0.322621 \\
\hline SE of regression & 0.217357 Sum s & dared resid & & 0.612321 \\
\hline F-statistic & 4.127458 Durbi & Watson stat & & 1.296243 \\
\hline \multirow[t]{2}{*}{ Prob (F-statistic) } & 0.025752 & & & \\
\hline & Unweighted Stat & tics & & \\
\hline R-squared & 0.735419 Mean & ependent var & & 0.718452 \\
\hline Sum squared resid & 0.857566 Durbi & Watson stat & & 1.296243 \\
\hline
\end{tabular}

Source: (Results of Eviews 10, 2019)

Table 6. Hausman Results

\begin{tabular}{|c|c|c|c|}
\hline TestSummary & Chi-Sq.statistics & Chi-Sq. df & Prob. \\
\hline Random cross-section & 2.058840 & 2 & 0.5603 \\
\hline Random period & 0.55587420 .3256 & & \\
\hline Cross-section and random period & 0.87521720 .4253 & & \\
\hline
\end{tabular}

Source: (Eviews 10 output results, 2019)

The Hausman test hypothesis is $\mathrm{HO}=$ the method used is the Fixed Effect Model and $\mathrm{H} 1$ = the method used is the random effect Model. Test criteria Hausman test is the probability value (prob.) Cross-section random value $>$ of $\alpha=5 \%$, the model chosen is the random effect model and the probability value (prob.) Cross-section random value $<$ of $\alpha=$ $5 \%$ then the model chosen was the fixed effect model.

0.5603 probability value> 0.05 so that $\mathrm{H}_{0}$ is received, which means the most appropriate model used is the random effect model. The random effect model is a model used to estimate panel data to determine the effect of good corporate governance and political connections on firm value. 


\section{Proving the hypothesis}

Good Corporate Governance has a positive and significant effect on Firm Value.

Table 7. The Effect of Good Corporate Governance on Firm Value

\begin{tabular}{ccccc}
\hline Variable & \multicolumn{2}{c}{ Coefficient Std. Error } & t-Statistic & Prob. \\
\hline C & 1.213645 & 0.513368 & 2.364086 & 0.0196 \\
CG & 0.776919 & 0.879331 & 1.993316 & 0.0291 \\
\hline
\end{tabular}

Source: (Outputs Eviews 10, 2019)

Based on the above table regression panel data estimation model Random Effect is $\mathrm{Y}$ $=1.213645+0.776919 \mathrm{X}$. The coefficient on the panel data regression model is 0.776919, meaning that everyone's increase in the variable of good corporate governance will add a firm value of $77.69 \%$.

The hypothesis in this study are:

$\mathrm{H}_{0}: \beta=0$ : good corporate governance does not affect the firm value

$\mathrm{H}_{\mathrm{a}}: \beta \neq 0$ : good corporate governance has a positive and significant effect on firm value

From the above calculation, it is known that the value of $\mathrm{t}$ count $=1.993316$ while the value $t$ table 1.978971, the calculated $t$ value is greater than the $t$ table and $\rho$ value 0.0291 with a significance level of 0.05 or the $\rho$ value is smaller than the alpha value.

This means that partially the implementation of good corporate governance has a positive and significant effect on firm value. This study is in line with the (Purbopangestu and Subowo, 2014) research but this study is not in line with the research of (Muryati and Suardikha, 2014).

Political Connection has positive and significant effect on Firm Value.

Table 8. The Effect of Political Connection on Firm Value

\begin{tabular}{ccccc}
\hline Variable & \multicolumn{2}{c}{ Coefficient Std. Error } & t-Statistic & Prob. \\
\hline C & 1.213645 & 0.513368 & 2.364086 & 0.0196 \\
KP & 0.286740 & 0.304889 & 1.980476 & 0.0488 \\
\hline
\end{tabular}

Source: (Outputs Eviews 10, 2019)

Based on the above table regression panel data estimation model Random Effect is $\mathrm{Y}$ $=1.213645+0.286740 \mathrm{X}$. Based on the table above it can be explained that each $1 \%$ increase in political connections will increase firm value by $28.67 \%$.

The hypothesis in this study are:

$\mathrm{H}_{0}: \beta=0$ : political connections do not affect the firm value

$\mathrm{H}_{\mathrm{a}}: \beta \neq 0$ : political connections have a positive and significant effect on firm value. 
From the above calculation, the calculated $t$ value $=1.980476$ while the value of $t$ table 1.978971, the calculated $t$ value is greater than the $t$ table and $\rho$ value 0.0488 with a significance level of 0.05 or the $\rho$ value is smaller than the alpha value.

This means that partially political connections have a positive and significant effect on firm value. This research is in line with research conducted by Mega (Dewanti, 2019) and (Wang et al., 2018) but contradicts the study of (Tangke, 2019).

Good Corporate and Political Connections together have a positive and significant effect on firm value.

Table 9. The Effect of Good Corporate and Political Connections on firm value

\begin{tabular}{l|l|l}
\hline R-squared & 0.735419 Mean dependent var & 0.718452 \\
\hline Adjusted R-squared & 0.857566 SD dependent var & 0.322621 \\
\hline SE of regression & 0.217357 Sum squared resid & 0.612321 \\
\hline F-statistic & 4.127458 Durbin-Watson stat & 1.296243 \\
\hline Prob (F-statistic) & 0.025752 & \\
\hline
\end{tabular}

Source: (Outputs Eviews 10, 2019)

From the above table, the known value of F count 4.127458 and 3.0681 and $\rho$ F table value is 0.025752 . This means that together corporate governance and political connections affect firm value.

The hypotheses in this study are:

$\mathrm{H}_{0}: \beta=0$ : good corporate governance and political connections do not affect firm value $\mathrm{H}_{\mathrm{a}}: \beta \neq 0$ : good corporate governance and political connections have positive and significant effects on firm value

In this study, the coefficient of determination is 0.735419 or $73.54 \%$. The coefficient of determination test is a test to find out how much influence all independent variables have on the dependent variable. This shows that the firm value of manufacturing companies in Indonesia in the study year amounted to $73.54 \%$ influenced by corporate governance or good corporate governance and the closeness of management with the authorities. Firm value is influenced by other variables outside the study by $26.46 \%$. This is very reasonable because the implementation of good corporate governance in Indonesia has not been run as well as possible so that investors will be attracted to companies that apply the principles of good corporate governance.

Political connections are still a reference for investors to invest their capital, this is reflected in the rising price of the company's shares that support the authorities, and vice versa. Businessmen will compete to provide support to prospective leaders in this country to get the political effect of the authorities. The politics of compassion in this country is still so large that it is this gap that entrepreneurs use to benefit from the leaders they support. 


\section{CONCLUSION}

Based on the above data analysis it can be concluded that: (1) Partially corporate governance has a positive and significant effect on firm value. This means that partially the implementation of good corporate governance has a positive and significant effect on firm value. This study is in line with the (Purbopangestu and Subowo, 2014) research but this study is not in line with the research of (Muryati and Suardikha, 2014). (2) Partially political connections have a positive and significant effect on firm value. This means that partially political connections have a positive and significant effect on firm value. This research is in line with research conducted by Mega (Dewanti, 2019) and (Wang et al., 2018) but contradicts the study of (Tangke, 2019). (3) Together corporate governance and political connections have a positive and significant effect on firm value. Political connections are still a reference for investors to invest their capital, this is reflected in the rising price of the company's shares that support the authorities, and vice versa. Businessmen will compete to provide support to prospective leaders in this country to get the political effect of the authorities. The politics of compassion in this country is still so large that it is this gap that entrepreneurs use to benefit from the leaders they support.

\section{REFERENCES}

Ang, James S; David K. Ding; and Tiong Yang Thong. (2013). Political Connection and Firm Value. Asian Development Review, Vol. 30, No. 2, pp. 131-166.

Asriyani, R., and Bandiyono, A. (2019). Complexity Of Annual License Notification Of Small-Medium Tax Business Taxes. Jurnal Akuntansi, 23(2), 316-332.

Bandiyono, A., and Aryani, S. D. (2019). Evaluation of Service Standards in the Information and Compliance Service Tax Office. Dinasti International Journal of Education Management And Social Science, 1(1), 55-66.

Bandiyono, A., and Augustine, Y. (2019). Organizational Performance As A Mediation On The Effect Of Levers Of Control And Learning Organization On Tax Compliance. International Journal of Business, Economics and Law-IJBEL.

Bandiyono, A., and Indrianto, N.P.P. (2019). E-Rekon LK Application as a Form of Accounting and E-Government Information Systems Implementation in Indonesia. International Journal of Innovation, Creativity and Change, 8(3), 23-40.

Bandiyono, A., and Murwaningsari, E. (2019). Effect of Intra Group Transaction, Thin Capitalization and Executive Characters on Tax Avoidation with Multinationality as a Moderation. Journal of Accounting, Business and Finance Research, 7(2), 82-97.

Bandiyono, A., and Pratama, L. W. (2019). Risk Cultural Evaluation As Organizational Culture In The Tax Service Office. Dinasti International Journal of Management Science, 1(2), 133-147.

Bianchi, Maria T., and Viana Rui Couto. (2014). "Political Connections: Evidence From Listed Companies in Portugal." International Journal of Economics and Accounting 5(1): 75. doi:10.1504/ijea.2014.060917.

Brigham, Eugene F and Joel F. Houston. (2014). Fundamentals of Financial Management, 14th Edition. Mason: South-Western Cengange Learning.

Chariri, A., dan Ghozali, I. (2007). Teori Akuntansi. Semarang: Badan Penerbit Universitas Diponegoro. 
Coulumb, Renaud, and Marc Sangnier. (2014). “The Impact Of Political Majorities On Firm Value: Do Electoral Promises Or Friendship Connections Matter?." Journal of Public Economics 115(2014): 158-170. doi: 10.1016/j.jpubeco.2014.05.001.

Dewanti Mega Rizky. (2019). Pengaruh Koneksi Politik Terhadap Nilai Perusahaan yang terdaftar di BEI. Surabaya. Artikel Ilmiah STIE Perbanas Thesis.

Ernawati dan Widyawati (2015). Pengaruh Profitabilitas, Leverage dan Ukuran Perusahaan Terhadap Nilai Perusahaan. Jurnal Ilmu \& Riset Akuntansi Vol. 4 No. 4 (2015).

Evianisa, Hermailinda. (2014). "Pengaruh Karakter Eksekutif dan Corporate Governance terhadap Tax Avoidace." Universitas Muhammadiyah Yogyakarta. Yogyakarta.

Faccio, Mara. (2006). Politically Connected Firms, Journal American Economic Assosiation, Vol. 96, No. 1, pp: 369-386.

Fadilah, Sri. (2011). Pengaruh Implementasi Pengendalian Intern dan Total Quality Management terhadap Penerapan Good Governance. Simposium Nasional Akuntansi XIV. Aceh.

Freeman, R. E., and McVea, J. (2001). A Stakeholder Approach to Strategic Management. The Blackwell Handbook Of Strategic Management, 189-207.

Hemastuti,C.P. (2014). Pengaruh Profitabilitas, Kebijakan Dividen, Kebijakan Hutang, Keputusan Investasi, dan Kepemilikan Insider Terhadap Nilai Perusahaan. Jurnal Ilmu \& Riset Akuntansi. Vol.3. No.4.

Irawan, N., dan Deviesa, D. (2017). Pengaruh Corporate Governance Terhadap Firm Value Dengan Financial Performance Sebagai Variabel Intervening Pada Perusahaan LQ 45 Tahun 2012-2015. Business Accounting Review, 5(1), 277-288.

Kim, C., and Zhang, L. (2016). Corporate Political Connections And Tax Aggressiveness. Contemporary Accounting Research, 33(1), 78-114.

Kristanto Agustinus Tri. (2019). Pengaruh Political Connections Terhadap Kinerja Perusahaan. EXERO Journal of Research in Business and Economics, Vol. 02, No. 01, Mei 2019.

Lukviarman, Niki. (2016). Corporate Governance. Solo: PT Era Adicitra Intemedia.

Muryati Ni Nyoman Tri Sariri dan Suardikha I Made Sadha. (2014). Pengaruh Corporate Governance pada Nilai Perusahaan. E-Journal Akuntansi Universitas Udayana 9.2(2014): 411-429.

Noerirawan Moch. Ronni dan Muid Abdul, (2012). "Pengaruh Faktor Internal dan Eksternal Perusahaan Terhadap Nilai Perusahaan”. Diponegoro Journal of Accounting Vol.1 No. 2, hal. 4.

Purbopangestu Hary Wisnu dan Subowo. (2014). Pengaruh Good Corporate Governance Terhadap Nilai Perusahaan dengan Corporate Social Responsibility Sebagai Variabel Intervening. Accounting Analysis Journal 3 (3).

Purwoto, Lukas. (2011). Pengaruh Koneksi Politis, Kepemilikan Pemerintah dan Keburaman Laporan Keuangan terhadap Kesinkronan dan Risiko Crash Harga Saham. Ringkasan Disertasi Program Doktor Ilmu Ekonomi Manajemen. Universitas Gadjah Mada.

Septianto, Reza, Sumiati dan Ainur Rofiq. (2017). Pengaruh Corporate Governance terhadap Firm Value Melalui Mediasi Capital Structure dan Financial Performance. Jurnal Bisnis dan Manajemen Vol. 4 No.1, Januari 2017. 
Sharma, Piyush; Cheng, Louis; Leung, T.Y. (2019). Impact of political connections on Chinese export firms' performance - Lessons for other emerging markets. Journal of Business Research. 10.1016/j.jbusres.2019.08.037.

Suad Husnan dan Enny Pudjiastuti. (2012). Dasar - Dasar Manajemen Keuangan. Edisi Keenam cetakan pertama. Yogyakarta: UPP AMP YKPN.

Suffah, Roviqotus dan Akhmad Riduwan. (2016). Pengaruh Profitabilitas, Leverage, Ukuran Perusahaan Dan Kebijakan Dividen Pada Nilai Perusahaan. Jurnal Ilmu dan Riset Akuntansi, Volume 5 Nomor 2, februari 2016.

Susanto, Y. K. (2013). Pengaruh Pengungkapan Sustainability Report terhadap Profitabilitas Perusahaan. Business Accounting Review, 1(2), 319-328.

Tambunan Mei Cyntia Sabrina, Muhammad Saifi dan Raden Rustam Hidayat. (2017). Pengaruh Good Corporate Governance terhadap Nilai Perusahaan. Jurnal Administrasi Bisnis (JAB) Vol. 3 N0. 1 Desember 2017.

Tangke Paulus. (2019). Pengaruh Political Connection dan Foreign Ownership terhadap Nilai Perusahaan Melalui Corporate Social Responsibility. Jurnal Akuntansi \& Keuangan Daerah Volume 14, Nomor 1, Mei 2019: 01-15.

Velnampy, T. (2013). Corporate Governance and Firm Performance: A Study of Sri Lankan Manufacturing Companies. Journal of Economics and Sustainable Development Vol. 4 (3), 228-235.

Wang, Fangjun, Luying Xu, Junrui Zhang, Wei Shu. (2018). "Political Connection, Iinternal Control and Firm Value: Evidence from China's Anti-Corruption Campaign." Journal of Business Research 86(1): 53-67. doi: 10.1016/j.jbusres.2018.01.045.

Wiagustini, Luh Putu. (2014). Dasar-dasar Manajemen Keuangan. Denpasar: Udayana University Press.

Wulandari, Tri. (2013). Analisis Pengaruh Political Connection dan Struktur Kepemilikan Terhadap Kinerja Perusahaan. Diponegoro Journal Of Accounting, Vol. 2, No. 1, Hal. $1-12$. 